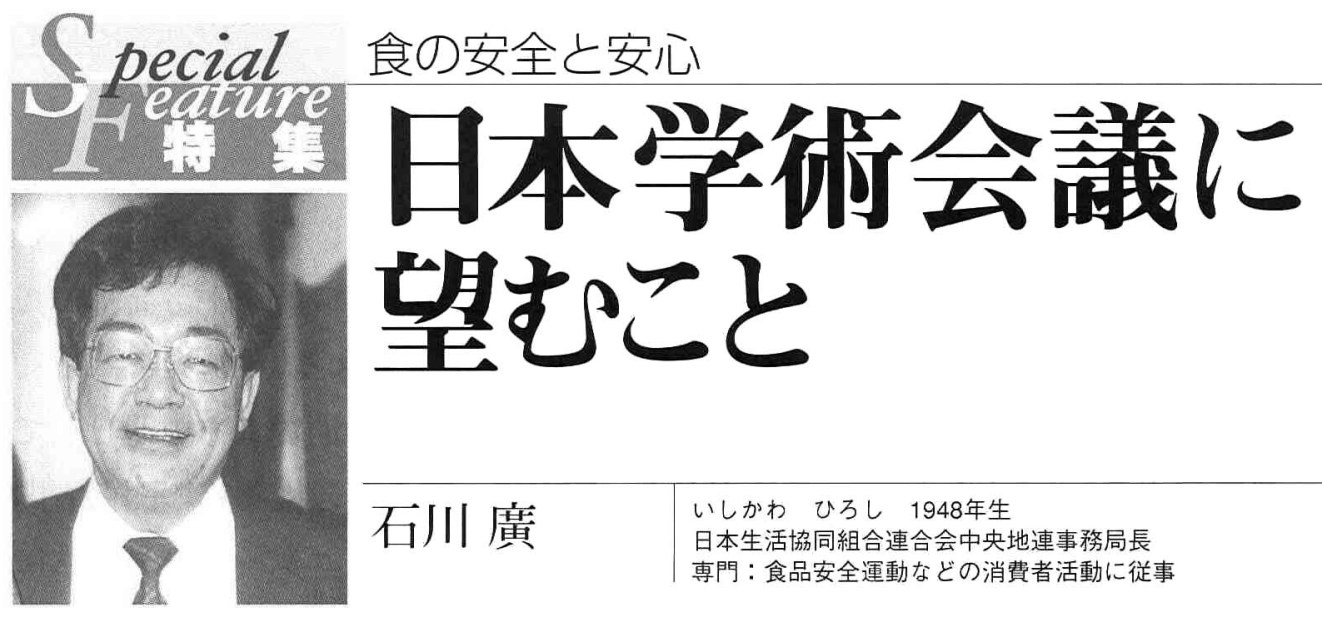

\section{1. 生協について}

まず、生協についてご理解をいただきたくご紹 介します。生協は消費生活協同組合法（昭和23年） に基づいて設立されており、消費者自身が出資・ 利用・運営する事業体としての消費者組織です。 したがって、店舗や共同購入等の事業とともに、 食品の安全性確保の運動をはじめとする様々な社 会的な諸活動にも積極的に取組んでいます。

現在、日本生協連に加盟する全国の生協数は約 600、そこに加入している組合員数は 2100 万人に まで増加しています。生協には地域生協や大学生 協、職域生協等の種類がありますが、地域生協に 加入している組合員の約 $95 \%$ は性であり、全国 平均で約30\%の世帯が生協の組合員となって生協 在利用しています。生協の事業高は3兆円を超え、 そのうち約75\%が食品の取扱い高です。

生協では、1960年代から有害添加物を排除した 独自のコープ商品開発や産直などの食への取組み を行ってきましたが、今日の生協の組合員の増加 も、こうした長年の取組みが支持されてきている ことの反映と考えています。

\section{2. 今日の食品安全問題}

近年、BSEやダイオキシン、環境ホルモン、人 畜共通感染症など、新しい食品安全問題が次々と
生じてきています。これらの問題は、後に述べる 食品衛生法の基本的な考え方である「清潔衛生の 原則」の視点からだけでは対応できない問題です。 また、グローバリゼーションの進展のなかで危害 が世界同時多発する状況にあります。BSEの国内 発生の問題は、こうした近年の国際化への対応が 大変立ち遅れていることを示しました。国際的な 安全確保システムの構築や、海外情報の収集・分 析、未然防止の国内制度や体制、対消費者も含め たリスクコミュニケーションの整備が必要になっ ています。食品安全行政が縦割りのままであるこ とも大きな問題です。

科学技術の進展によって、「ゼロリスク」食品は ありえないことが明らかになり、食品の安全性は クロかシロかだけでは論じられなくなっています。 こうした状況に対応して、すでに欧米では社会シ ステムとしてのリスクアナリシス手法の導入が図 られるようになってきています。しかし、日本で は、食品リスクに関する今日的な認識について、 社会的理解の促進が大きく立ち遅れてきたといえ ます。食品安全に携わる行政機関に执いても、リ スクアナリシスなるものについての認識が進んで きたのは、わずかにこの $2 、 3$ 年のことといえます。

もう一点、食品安全と産業振興の問題をあげた いと思います。産業革命以降、生産の桩大が経済 成長や豊かさを実現するものとみなされてきまし 
た。しかし、今日、改めて生産とは何か、くらし や安全性の視点から改めて考えられる必要があり ます。科学技術の進展や産業の発展は、消費者に とってのより良いくらしの実現のためであり、食 品については安全性の確保が前提とならなければ ならず、そのことを忘れた産業振興であってはな りません。

\section{3. 現在の食品安全行政の問題点}

日本の食品安全行政の中心は食品衛生法でした。 この食衛法には、今日的に大きな問題点がありま す。その一つとして、安全性確保の基本的な考え 方が「清潔衛生の原則」だけでは今日の食品安全問 題に対応できないことは先に述べました。

さらにいくつかの問題があります。現在の食衛 法には、国の責務が規定されておらず、裁量権の みを定めているという問題です。国が行うべき事 項についての食衛法の条文はことごとく「厚生労働 大臣は…できる」と書かれ打り、裁量行政には大 変都合の良い法律だと言えます。

昨年の秋に、日本生協連は食品安全に関する欧 州調査を行いました。欧州の法律の条文は、EUの 食品法や英国の食品基準法をとってみても、食品 の安全確保に関して国等が行わなければならない 事項は「‥しなければならない」と書かれており、 国・行政の責務が明確に示されています。こうし た欧米の法律と比較して、日本の食品安全の関連 法体系は法治国家として考えた場合、大変立ち遅 れています。

もう一つの問題点は、現在の食衛法が、行政が 事業者を取り締まることを主旨とするもので、消 費者・国民が法の当事者とは位置づけられていな いことです。消費者は、行政が事業者を取り締ま る結果として、反射的にその利益を得るというも
のです。食品危害の直接の被害者である消費者が 位置づけられていないということは、どう考えて も納得がいくものではありません。まして、リス クアナリシスの考え方に立てば、消費者抜きに今 日的な商品安全を確保できる社会システムは考え られないものです。

また、今日、ITやバイオ、ナノテク等の先端的 な科学技術が脚光を浴びていますが、食品安全に 係る科学技術を重視し、さらに発展させる必要が あります。現在、食品安全に係る調査・研究は大 変地味なものとされています。2000年の雪印乳業 の大規模食中毒事件の際には、食中毒の原因物質 の特定にも多くの時間を費やしました。流通が大 規模・広域化している現在、こうした基礎的な事 項の分析技術の開発を促進し、迅速な対策が行え るようにすることも不可欠です。食品安全に係る 海外情報や文献についても、体系的に収集し、分 析、発信する体制も整備が必要です。

問題点をいくつか述べましたが、この間、ジェ ノバサミット、沖縄サミットの共同宣言の中でも 食品安全問題の重要性が取り上げられています。 しかし、日本国内ではこの共同宣言に盛り込まれ た食品安全の重要性への言及にはほとんど関心が 払われてきませんでした。

\section{4. 食品安全基本法の制定、 食品衛生法等の改正と今後の課題}

全国の生協と日本生協連は、食品衛生法の抜本 改正を求めて、足掛け 5 年の運動を進めてきまし た。この運動では、約1400万人に上る請願署名や 地方議会での意見書採択が取組まれました。国会 請願では、衆参両院の4分の3にあたる国会議員の 賛同・紹介をいただき、法改正の請願が国会で採 択され (2001年秋)ました。こうした生協の取組 
みもあって、現在、国会で食品安全基本法制定や 食衛法改正等の審議が行われているものと理解し ています。

基本法や改正食衛法のあり方についても、様々 な場で提案・提言を行ってきました。それらは、 生協が消費者自身の組織、事業体として、消費者 の立場から、生産と流通、消費の現場に携わって きた経験が可能にしたものだったということがで きます。現在、論議されている基本法制定をはじ めとする今回の食品安全行政に係る法制度の改革 は、戦後日本の食品安全行政の大転換につながる ものと考えますが、その法の運用、実効性の確保 が今後の重要な課題だと認識しています。

今後に求められる課題は、リスク評価機関でも ある食品安全委員会が、厚生労働省や農林水産省 などのリスク管理機関や事業者からの独立性、科 学の粋を集めてリスク評価を行う卓越性、リスク コミュニケーションを前提とした公開性をどう確 保するかにあります。都道府県の食品安全行政の 強化も不可欠です。

コーデックス委員会は、各国に対して消費者も 参加する国内コーデックス委員会の設置を求めて います。しかし、日本には国内コーデックス委員 会はいまだ設置されていません。現在、コーデッ クス委員会の日本のコンタクトポイントは、文部 科学省に置かれていますが、その機能は極めて不 十分です。食品安全委員会はリスクアセスメント を主として担う機関とされていますが、コンタク トポイントは食品安全委員会に移管し、国際的な 情報収集も含めて強化していくことが必要です。

厚労省の食品安全に関する部局の機能・体制も 抜本的に強化する必要があります。米国では、各 国の食品安全に係る法制度や規制・基準の実情、 生産段階における管理実態の調査・情報収集を海
外現地の体制も含めて強化し、必要な国内対策を 行うと同時に、国内への情報提供を積極的に行っ ているとされています。グローバル化の進展のな かで、日本でもこうした対応が必要です。

都道府県の食品安全行政強化の点でいえば、食 衛法に基づく監視・指導計画を年次で策定し、公 表することとされています。計画策定・検討段階 からの消費者の参加や実施状況の情報の公開も積 極的に行われる必要があります。

\section{5. 日本学術会議への期待}

科学技術は飛躍的に発展し、私たちの生活に非 常に重要な役割を果たしています。しかし、科学 技術に対する信頼は必ずしも磐石のものとはなっ ていません。

そこで一番の問題として考えられることは、そ もそも日本学術会議とはどんなところなのか、何 をしているのかが一般の人にはほとんど知られて いないことです。そこを解決することが、まず大 切ではないでしょうか。加えて、先ほど述べたよ うに、先端技術だけでなく、地味かもしれないが、 食品安全に係る科学研究や専門家の養成にも力を 入れて欲しいと考えます。その際、ハザードの同 定やリスクアセスメントなどにかかわる専門学術 の進展をはかることがもちろん重要です。あわせ て、リスクマネジメント、リスクコミュニケーシ ヨン等、社会制度論にまで立ち入った学際的学術 体系として食品安全の学術を発展させることが要 請されていると考えます。

日本学術会議の活動が、国民の目に明らかに映 るためには、そして科学技術に対する信頼を一層 確立していくためには、食品の安全・安心の課題 を重視し、より積極的に社会的な発信を行い、国 民の間での認知と信頼を得ていくことが必要だと 
思います。

その意味では、全米科学アカデミーの活動が参 考になるのではないでしょうか。米国でもサッカ リンの安全性をめぐって大きな社会的論争があっ たと聞いています。

サッカリンはデラニー条項〔その量の如何を問わ ず、発ガン性の疑いのある食品添加物は食品に使 用してはならない (1958年)、ただし、この条項は 1997年に削除】に抵触するおそれれがあとして （1972年）、FDA（米国食品医薬品局）はその使用を 禁止（1977年）しました。しかし、健康上の理由か らサッカリンを必要とする人たちの要請によって 禁止は延期されました。その際、全米科学アカデ ミーは、様々な科学的検証と議論を行い、結論と して、発ガン性があったとしても、それが社会的
に許容できる程度であれば、リスクアセスメント を行った後、国民に選択させることを提言しまし た。以来、FDAは、de minimis (極微小) 原則を 採用しています。

こうした、議論の前提には、客観的な科学的検 証の積み重ねと、その結果の情報の公開が前提と なることは当然です。日本学術会議には、全米科 学アカデミーのように、国民に姿が見える科学者 集団としての積極的な社会的発言を期待します。

この原稿は、平成15年4月25日に行われた第8回日本学術 会議「牛海綿状脳症 (BSE) と食品の安全特別委員会」におい て行われた意見聴取の際の記録をもとにしたものである。

\section{学術の動向「平成15年12月号」の予告（平成15年12月1日発行予定）}

\section{特集「日本学術会議第141回総会」}

\section{特集「第19期日本学術会議の活動計画と各部の抱負」}

執筆者

蓮見音彦 (日本学術会議第1部長)

広渡清吾 (日本学術会議第2部長)

西澤 俢 (日本学術会議第3部長)

鄉 信広 (日本学術会議第4部長)

久米 均 (日本学術会議第 5 部長)

祖田 修 (日本学術会議第6部長)

鴨下重彦 (日本学術会議第7部長) 